EESTI NSV TEADUSTE AKADEEMIA TOIMETISED. IX KOIDE FOOSIKALIS-MATEMAATILISTE JA TEHNILISTE TEADUSTE SEERIA. 1960, NR. 2

ИЗВЕСТИЯ АКАДЕМИИ НАУК ЭСТОНСКОИ ССР. ТОМ ІХ СЕРИЯ ФИЗИКО-МАТЕМАТИЧЕСКИХ И ТЕХНИЧЕСКИХ НАУК. 1960, № 2

\title{
К ВОПРОСУ О СТРОЕНИИ КЕРОГЕНА
}

\author{
н. Л. ДилАКТОРСКии, \\ доктор геолого-минералогических наук
}

На основании имеющихся в литературе описаний тонкого строения керогена кукерсита $[1,4]$ можно представить, что он состоит из двух частей: количественно преобладающей бесструктурной окрашенной в желтый или светло-коричневый цвет органической массы и включенных в нее темно-коричневых или бурых форменных элементов, представленных сферическими, яйцевидными или бобообразными зернами размером or 2 до $5 \mu$. Последние, согласно представлениям $M$. Д. Залесского ['], являются сохранившимися до наших дней остатками колоний водорослей Cloeocapsomorpha prisca.

Естественно, что следствием такого строения керогена был бы неодинаковый химический состав составляющих его частей и вытекающее из этого неодинаковое поведение их при химической обработке. Однако, как известно, опыты по деструкции керогена не обнаружили какой-либо стадийности в прохождении реакций при его термической обработке или окислении - он всегда вел себя как однородное вещество $\left[{ }^{2}, 5\right]$.

Явное противоречие между морфологическим составом и химическими особенностями керогена, не находившее себе должного объяснения, побудило нас еще раз вернуться к изучению его строения.

Исходным материалом для работы служили пробы товарного сланца второго сорта, пробы из шахты № 10 (Ахтме) и пробы из известкового прослоя (C-D) той же шахты. Количество органической массы (керогена) в указанных пробах колебалось от 4,8 до $50,9 \%$.

Извлечение керогена из пробы проводилось либо отделением в тяжелых жидкостях из порошка сланца, полученного размолом кукерсита в шаровой мельнице до зерен размером менее 0,074 мм, либо разделением в тяжелых жидкостях остатка, полученного после дезинтеграции кусков сланца серным эфиром с последующей обработкой порошка $3 \%$-ной соляной кислотой до полного растворения карбонатов.

Определение показателей светопреломления зерен керогена, полученных различными способами, и сравнение их с показателем светопреломления керогена, полученного простым измельчением проб (без последующей обработки кислотами и тяжелыми жидкостями), показало близкую во всех случаях величину светопреломления органической массы $(1,563 \pm 0,005)$, что свидетельствует об отсутствии заметного воздействия применявшихся реагентов на кероген.

Обычная картина, наблюдаемая при рассмотрении сгустков керогена под микроскопом при увеличении в 500 раз, показана на фиг. 1. На фо- 
тографиях видна основная, светлая (желтая) изотропная масса, внутри которой размещаются темные скопления.

При еще большем увеличении удается рассмотреть также отдельные овальные и бобовидные включения, описанные в свое время М. Д. Залесским и Л. Ф. Фокиным $[1,4]$, а также включения скорлуповидной, листообразной и почти нитевидной формы.

Граница, отделяющая эти включения от вмещающей их основной массы, очень резка. Это говорит о значительной разнице в величинах показателей светопреломления, причем показатель светопреломления основной массы много больше, чем у включений.

Это обстоятельство, а также характер распределения и форма включений навели на мысль об ином, не органическом составе включений, так как органическое, сложного состава вещество ядер сине-зеленых водорослей вряд ли могло обладать столь малой величиной показателя светопреломления. Вероятней было предположить газовый или жидкостный характер включений.

Так как в обычных прозрачных шлифах толщиной около 0,03 мм мелкие включения, размер которых колеблется от 2 до $7 \mu$, располагаются в несколько слоев, что сильно затрудняет наблюдение отдельных зерен, было решено попытаться изготовить возможно более тонкие срезы из сгустков керогена.

После ряда предварительных опытов, показавших применимость предложенного метода к. новому материалу, была изготовлена серия вмонтированных в канадский бальзам коллоидиновых срезов керогенных сгустков толщиной от 3 до $6 \mu$.*

Первый же взгляд на полученные препараты полностью подтвердил наши предположения: в тонких пластинках керогена темных телец не оказалось! Вместо них просматривались лишь контуры вскрытых разрезом включений, заполненных иммерсионной средой. Кое-где были заметны и отдельные темные тельца, но и они, при ближайшем рассмотрении, оказывались либо кристалликами марказита, либо не вскрытыми разрезом полостями, заполненными газом (фиг. 2-5).

Для подтверждения сделанных наблюдений, шедших вразрез с прочно установившимися в. науке предположениями об органическом составе включений, было предпринято растирание керогена в агатовой ступке.

Исследование полученного тонкого порошка в иммерсии показало отсутствие в керогене каких бы то ни было остатков темных ядер. Вместе с незначительным количеством минеральных частиц, загрязнявших кероген (марказит, кальцит, кварц, гидрослюды), наблюдались лишь зерна керогена со вскрытыми и невскрытыми порами (фиг. 6 .

Тонкие шлифы известняковых прослоек (C-D), содержавшие отдельные сгустки (зерна) керогена, показали ту же самую картину: овальной формы газовые пузырьки, включенные в органическую массу.

Наличие газа в полостях керогена было доказано растиранием сгустков, помещенных в масло, между двумя толстыми плоско шлифованными стеклами. Бо́льшая часть зерен керогена оказалась в результате этой манипуляции раздавленной, темные включения, в которые вместо выдавленного газа проникла иммерсионная жидкость, светлели, а в масле появлялись мельчайшие, ранее отсутствовавшие в нем пузырьки газа.

Наконец, откачивание воздуха из пробирки, содержавшей погружен-

* Срезы изготовлены старшим научным сотрудником Института экспериментальной и клинической медицины АН ЭССР Г. Е. Лоогна, которому автор выражает свою искреннюю благодарность. 
ный в жидкое минеральное масло кероген, дало возможность после снятия вакуума обнаружить просветление пузырьков, расположенных на периферических участках некоторых сгустков, потерявших при вакуумировании часть включенного в них газа.

Аналитических данных о составе извлеченного из полостей газа не имеется. В литературе [3] имеются указания на выделение заметного количества газов, главным образом углекислоты, при вакуумировании кукерсита. По мнению Лутса [3], эти газы находятся в адсорбированном состоянии на поверхности и в микротрещинах керогена.

Поскольку при вакуумировании неизмельченных сгустков керогена подавляющая часть газовых включений остается сохранной, появляется возможность извлечения и анализа газа, заполняющего эти полости. Для этого достаточно произвести тонкий помол в вакууме предварительно обезгаженного порошка керогена.

Выделенный из слоев A, B, C, D и Е кероген после тщательного обезгаживания его под вакуумом измельчался в вакуумной шаровой мельнице. Эвакуация высвободившихся из полостей пузырьков газов проводилась при нагревании пробы до 100 градусов.* Данные о составе собранных газов помещены в нижеследующей таблице.

При удалении газов, сорбированных на

\begin{tabular}{l|l|l|l}
\hline \multirow{2}{*}{$\begin{array}{c}\text { Кероген из } \\
\text { слоев }\end{array}$} & \multicolumn{2}{|c|}{ Содержание, \%* } \\
\cline { 2 - 4 } & $\mathrm{CO}_{2}$ & $\mathrm{H}_{2}$ & $\mathrm{CH}_{4}$ \\
\hline A и B & 60,0 & 20,2 & 18,8 \\
$\mathrm{~A}, \mathrm{~B}, \mathrm{C}, \mathrm{D}$ и E & 60,0 & 26,6 & 13,4
\end{tabular}
поверхности сгустков керогена до его измельчения, выделялся лишь углекислый газ.

Проведенные опыты показали практически одинаковый состав газов, заключенных в керогеновых сгустках, выделенных из различных слоев. Это позволяет сделать предварительное заключение (до оконча-

* По данным М. М. Элинсон. тельной проверки его на большем количестве материала) о сравнительном постоянстве условий - температуры, окислительно-восстановительного потенциала среды и др., - господствовавших во время преобразования илистых органических образований в сгустки керогена.

Общая картина возникновения структуры керогена, вырисовывающаяся на основании проведенных наблюдений, представляется в следующем виде.

Кероген - вещество, не сохранившее состава и следов строения первичной органической массы.

По-видимому, илистая органическая масса, длительно находившаяся

* Работу по проведению названных опытов любезно согласилась взять на себя сотрудница кафедры геологии и разведки месторождений природных газов и нефти Московского геолого-разведочного института им. Орджоникидзе М. М. Элинсон.

Фиг. 1. Отдельные зерна керогена с темными включениями $(\times 500)$.

Фиг. 2. Тонкий срез зерна керогена. Видны и вскрытые (светлые) и не вскрытые (темные) разрезом полости $(\times 450)$.

Фиг. 3. Тонкий срез зерна керогена с полостями, вскрытыми разрезом $(X 1250)$.

Фнг. 4. Тонкий срез части зерна керогена. Хорошо заметно глобулярное строение органического вещества $(\times 1000)$.

Фиг. 5. Тонкий срез части зерна керогена. Видны две невскрытые полости, заполненные газом $(\times 1250)$.

Фиг. 6. Кероген, растертый в ступке: $a-$ зерно со вскрытыми газовыми полостями; 6 - зерно с одной вскрытой и другой не вскрытой при растирании газовой полостью $(\times 1250)$. 

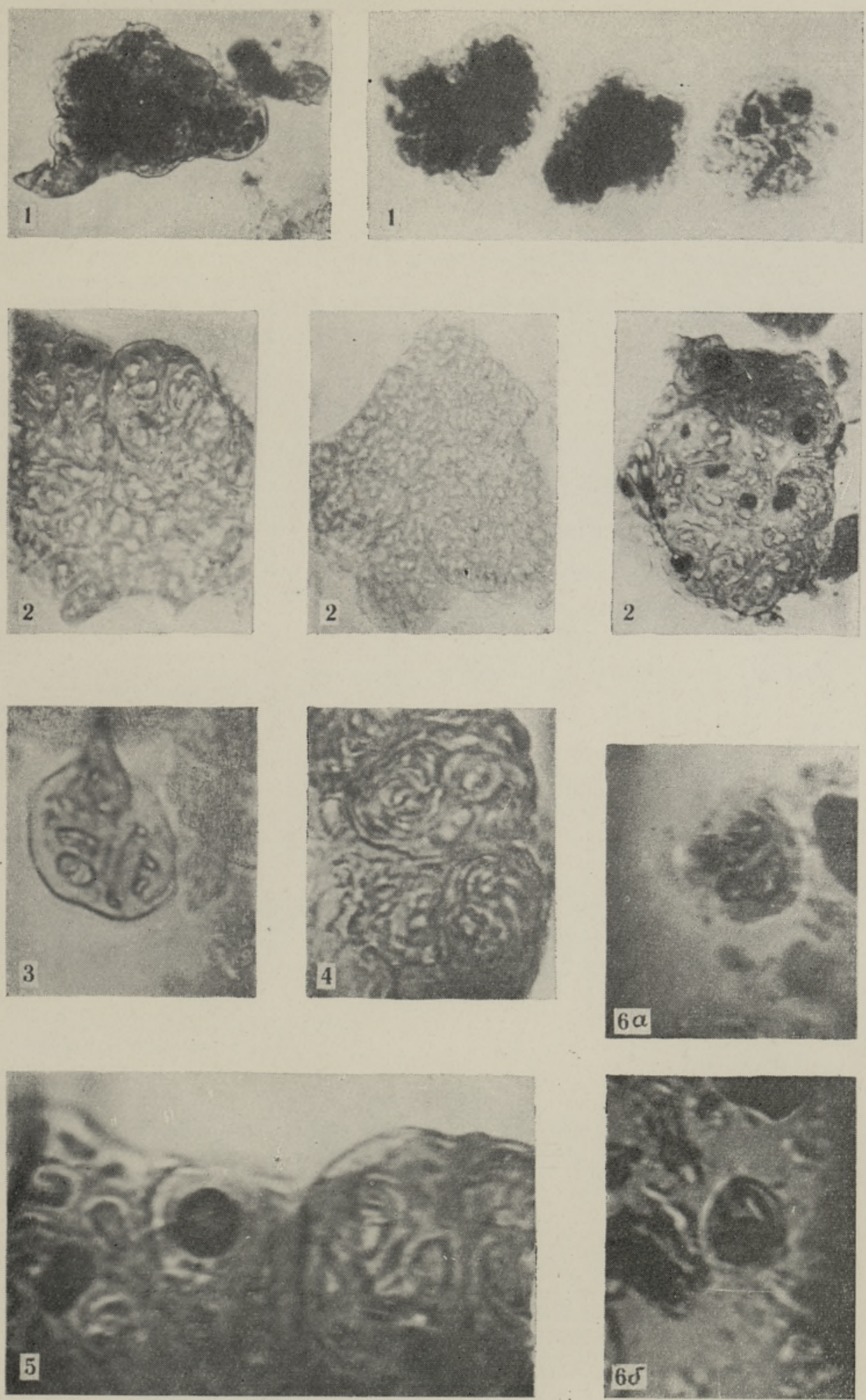
в придонной зоне морского бассейна, подвергалась процессам разложения и преобразования в присутствии весьма ограниченных количеств кислорода.

Этот процесс привел к изменению первоначального состава органической массы: переходу ее из илистого в гелеподобное состояние.

Коагуляция и постепенное уплотнение геля послужили причиной возникновения глобулярного строения органической массы керогена.

Прекратившееся ко времени уплотнения поступление кислорода обеспечило сохранность органической массы, продолжавшей, однако, преобразовывать свой состав.

Образование газовых включений следует отнести ко времени значительного уплотнения органической массы.

\title{
ЛИТЕ Р А Т Р Р А
}

1. М. Д. 3 а лесє к и й, О морском сапропелите силурийского возраста, образованном сине-зеленою водорослью, Известия Академии наук, сер. II, № XI, 1917.

2. К. А. К а ск, О битуминизации керогена сланца-кукерсита, Тр. Таллинск. политехн. ин-та, сер. А, № 63, 1955.

3. K. Luts, Der estländische Brennschiefer-Kukersit. Seine Chemie, Technologie und Analyse, 1934 .

4. Ф. Л. Фокин, О строении и продуктах распада битуминозных горных пород Әстляндии, Горный журнал, т. II, № 12, 1913.

5. А. С. Фомин а и Л. Я. Побуль, Окислительная деструкция керогена кукерсита, Изв. АН ЭССР, т. ІІ, № 1, 1953.

Институт строительства и строительных материалов Академии наук Эстонской ССР

\section{Поступила в редакцию}

21. XII 1959

\section{KEROGEENI EHITUSEST}

\author{
N. Dilaktorski, \\ geoloogia-mineraloogiadoktor
}

\section{Resümee}

Eesti põlevkivi kerogeeni terade $3-6 \mu$ paksuste lōikude uurimine näitas, et neis esinevad tumedavärvilised sfäärilised, muna- või oakujuliste piirjoontega elemendid, mis M. Zalesski ['] arvates kujutavad enesest meie päevini säilinud sinakasroheliste vetikate Cloeocapsomorpha prisca kolooniaiđ̂, on tegelikult olnud gaasidega täidetud tühemid (vt. tabel).

Eesti NSV Teaduste Akadeemia

Ehituse ja Ehitusmaterjalide Instituut
Saabus toimetusse

21. XII 1959

\section{ZUR FRAGE VON DER STRUKTUR DES KEROGENS}

\section{N. Dilaktorski}

\section{Zusammenfassung}

Es wurden 3-6 $\mu$ starke Schnitte von Kerogenkörnern des baltischen Brennschiefers untersucht. Dabei zeigte es sich, dass die dunkelgefärbten Formenelemente von sphärischem, ei- oder bohnenförmigem Umriss, die nach der Bestimmung von $M$. D. Zalesski [ $\left.{ }^{1}\right]$ Kolonien von blaugrünen Algen Cloeocapsomorpha prisca sein sollen, in Wirklichkeit verschiedenförmige, mit einer Gasmischung gefüllte Höhlungen darstellen (siehe Tabelle im Text des Auísatzes). 